\title{
PENGARUH PERSEPSI MASYARAKAT BATAM TENTANG BANK SYARIAH TERHADAP MINAT MENGGUNAKAN PRODUK BANK SYARIAH
}

\author{
$\operatorname{Imran}^{1}$ ), Bambang Hendrawan ${ }^{2}$ ) \\ 1) Prodi Administrasi Bisnis, Politeknik Negeri Batam, email: imranrezha@yahoo.co.id \\ 2) Prodi Administrasi Bisnis, Politeknik Negeri Batam,, email: benk07@gmail.com
}

\begin{abstract}
This research examines the influence of society's perception about sharia bank toward intends to use sharia bank products. The data collection technique was a field survey that using questionnaire to the sample respondents. Sampling method used is accidental sampling method with 100 selected people by accidently. The data analysis method uses multiple linear regression model. The result of this research indicate that people perception about bank sharia in banking system with interest, profit sharing system characteristics and sharia product knowledge, simultaneously have positive significant effect toward intends to use sharia product. Partially, only perception from knowledge of product variable has no influence toward society intends to Sharia bank products. Its means the better understanding about the no-interest banking system and also about profit sharing system as a basis for sharia bank practices, will increase society's intends to use sharia products. Meanwhile, there is no effect for society perception whether they have a better or less knowledge of sharia bank products
\end{abstract}

Keywords : Sharia Bank, Perception, interest, profit sharing, product knowledge, Batam

\begin{abstract}
Abstrak
Penelitian ini menguji pengaruh persepsi masyarakat tentang bank syariah terhadap minat menggunakan produk bank Syariah. Bank syariah adalah bank yang beroperasi dengan tidak mengandalkan pada bunga. Bank Islam atau biasa disebut dengan bank tanpa bunga, adalah lembaga keuangan atau perbankan yang operasional dan produknya dikembangkan berlandaskan pada Al Qur'an dan Hadis Nabi Muhammad SAW. Persepsi tentang bank syari'ah terdiri dari atas 3 tiga variabel, yaitu: persepsi tentang bunga bank, persepsi tentang sistem bagi hasil, dan persepsi tentang produk bank syari'ah. Teknik pengumpulan data menggunakan kuesioner. Jumlah sampel sebanyak 100 orang masyarakat yang tinggal di kawasan Batam Center. Metode analisis data yang digunakan dalam penelitian ini model analisis linier berganda dengan uji hipotesis menggunakan uji $\mathrm{F}$ dan uji t. Hasil penelitian menunjukkan bahwa pertama, persepsi tentang bunga bank berpengaruh secara positif dan signifikan terhadap minat menggunakan produk bank syariah. Kedua, persepsi tentang sistem bagi hasil berpengaruh secara positif dan signifikan terhadap minat menggunakan produk bank syariah. Ketiga, persepsi tentang pengetahuan produk bank syariah tidak berpengaruh terhadap minat menggunakan produk bank syariah.
\end{abstract}

Kata kunci: Persepsi Tentang Bunga Bank, Sistem Bagi Hasil, Produk Bank syariah. 


\section{PENDAHULUAN \\ Latar Belakang}

Perbankan merupakan suatu lembaga yang sangat penting dalam kehidupan suatu negara, apalagi negara yang sedang berkembang seperti Indonesia. Peran strategis tersebut terutama disebabkan oleh fungsi utama Bank sebagai lembaga yang dapat mengumpulkan dan menyalurkan dana nasabah atau masyarakat secara efektif dan efisien. Dengan berperan sebagai perantara antara pihak yang berkelebihan dana dan yang kekurangan dana, sehingga dana tersebut diharapkan dapat memberikan kemanfaatan yang besar bagi masyarakat, serta diberi kebebasan untuk memilih antara Bank Syariah dan Bank Konvensional. Bagi mereka yang mempunyai kekhawatiran adanya bunga Bank (riba) maka Bank Syariah bisa menjadi alternatif yang lebih inovatif sebagai sarana peminjaman modal ataupun menginvestasikan dana. Menurut Muhammad (2005) Bank syariah adalah bank yang beroperasi dengan tidak mengandalkan pada bunga. Bank Islam atau biasa disebut dengan bank tanpa bunga, adalah lembaga keuangan atau perbankan yang operasional dan produknya dikembangkan berlandaskan pada $\mathrm{Al}$ Qur'an dan Hadis Nabi Muhammad SAW. Dengan kata lain bank Syari'ah adalah lembaga keuangan yang usaha pokoknya memberikan pembiayaan atau kredit dan jasa-jasa lainnya dalam lalu lintas pembayaran serta peredaran uang yang pengoperasiannya disesuaikan dengan prinsip syariat Islam.

Bank syariah memiliki produk atau jasa yang tidak ditemukan dalam operasi bank konvensional. Prinsip-prinsip seperti musyarakah, mudharabah, murabahah, ijarah, istishna dan sebagainya tidak memuat adanya prinsip-prinsip bunga seperti yang dikembangkan oleh bank konvensional. Pandangan masyarakat terhadap lembaga keuangan syariah di antaranya dapat mewakili dengan pandangan masyarakat secara umum terhadap perbankan syariah. Kesan umum yang ditangkap oleh masyarakat tentang perbankan syariah adalah (1) perbankan syariah tidak ada bunga (2) perbankan syariah identik dengan bank sistem bagi hasil. Namun demikian, ternyata persepsi dan sikap masyarakat terhadap bunga bank dan sistem bagi hasil sangat beragam. Sebagian masyarakat tetap menerima bunga, sebagiannya lagi menerima sistem bagi hasil. Sikap yang mencampur adukkan berbagai paradigma ini, memberi nuansa yang cukup menarik sebagai gambaran tentang sikap, pengetahuan, persepsi serta perilaku masyarakat dalam menyikapi kebijakan dual banking system tersebut. Perbankan syariah mengharamkan sistem bunga dan menghalalkan bagi hasil. Akibatnya adanya perbedaan antara investasi dan pembuangan uang. Investasi merupakan usaha yang dilakukan mengandung resiko dan mengandung unsur ketidakpastian. Sebaliknya, pembuangan uang adalah aktifitas yang tidak memiliki resiko karena adanya persentase suku bunga tertentu yang diterapkan berdasarkan besarnya modal.

Beragamnya persepsi, sikap dan perilaku masyarakat terhadap bank syari'ah, diantaranya disebabkan oleh rendahnya pemahaman dan pengetahuan masyarakat terhadap bank syari'ah, terutama yang disebabkan dominasi bank konvensional. Perbedaan persepsi atas bagi hasil, bunga dan produk sangat berpotensial mempengaruhi minat masyarakat menggunakan produk bank syariah, sehingga perlu dilakukan penelitian lebih lanjut mengenai pengaruh perbedaan persepsi atas bagi hasil, bunga bank dan produk terhadap minat menggunakan produk bank syariah.

Berdasarkan latar belakang, maka rumusan masalah yang diajukan adalah bagaimanakah pengaruh persepsi masyarakat Batam tentang bank syariah terhadap minat menggunakan produk bank syariah.

\section{Tujuan Penelitian}

Adapun tujuan dari penelitian ini adalah untuk mengetahi bagaimanakah pengaruh persepsi masyarakat Batam tentang bank syariah terhadap minat menggunakan produk bank Syariah (studi kasus masyarakat Citra Batam)

\section{KAJIAN PUSTAKA \\ Kajian Empiris}

Penelitian ini mengacu pada penelitian sebelumnya untuk mempermudah dalam pengumpulan data. Adapun penelitian terdahulu yang menjadi referensi pada penelitian ini adalah sebagai berikut:

(1) Penelitian mengenai Pengaruh Persepsi Tentang Bank Syariah Terhadap Minat Menggunakan Produk di Bank BNI Syariah Semarang yang dilakukan oleh Anita rahmawaty (2014), dimana temuan penelitiannya menunjukkan bahwa persepsi tentang bunga bank dan bagi hasil berpengaruh secara positif dan signifikan 
Imran \& Bambang Hendrawan,Pengaruh Persepsi Masyarakat Batam tentang Bank...

terhadap minat menggunakan produk bank syariah. Sedangkan persepsi tentang produk bank Syariah tidak berpengaruh terhadap minat menggunakan produk bank syariah

(2) Penelitian mengenai Pengaruh Pesepsi Bunga Bank dan Kualitas Layanan Terhadap Minant Menabung Pada Bank BNI Syariah di Kota Semarang yang dilajukan oleh Asih Fitri, Saryadi dan Sendhang Nurseto (2013) dimana hasil dari analisis regresi, penelitian ini menunjukkan bahwa persepsi bunga bank dan kualitas pelayanan berpengaruh signifikan terhadap minat menabung pada Bank BNI Syariah di Kota Semarang $36,3 \%$ dan $47,2 \%$

(3) Penelitian dengan judul Faktor-faktor yang mempengaruhi minat masyarakat dalam berhubungan dengan bank syariah di Kota Padang yang dilakukan oleh Neng Kamarni (2012). Hasil menunjukkan bahwa variabel agama, pengetahuan tentang keberadaan bank syariah dan pengetahuan produk tentang mekanisme bank syariah tidak berpengaruh secara signifikan dalam berhubungan dengan bank syariah, sedangkan variabel tenaga kerja, tingkat pendapatan, tingkat pengeluaran dan preferensi berpengaruh secara signifikan dalam berhubungan dengan bank syariah.

(4) Penelitian mengenai Analisis Faktor yang Mempengaruhi Nasabah (Mahasiswa) dalam Memilih Menabung pada Bank Syariah yang dilakukan oleh Ananggadipta Abhimantr, Andisa Rahmi Maulina dan Eka Agustaningsih. Hasil penelitian menunjukkan bahwa faktor-faktor seperti pengetahuan, religiusitas, produk, reputasi dan pelayanan di Bank Syariah memiliki pengaruh positif terhadap keputusan memilih menabung di Bank Syariah, meskipun tidak signifikan

(5) Penelitian yang berjudul Factors Influencing the Perception of Customerin Islamic Banking: A Case Study in Pakistan oleh Naem Akhtar Muhammad Toqeer Mehmood, dkk (2016). Hasil penelitian ini menunjukkan bahwa ada kriteria persepsi yang signifikan mengenai perbankan syariah. Faktor yang paling penting yang berpengaruh pada persepsi pelanggan dalam perbankan Islam adalah agama, kesadaran tentang ajaran keuangan Islam, kesadaran mengenai produk IB dan layanan, iklan, jaringan.

\section{Kajian Teori}

\section{Falsafah Bank Syariah}

Setiap lembaga keuangan syariah mempunyai falsafah mencari keridhoan Allah untuk memperoleh kebajikan di dunia dan akhirat. Oleh karena itu, setiap kegiatan lembaga keuangan yang dikhawatirkan menyimpang dari tuntunan agama harus dihindari. Berikut adalah falsafah yang harus diterapkan oleh bank syariah (Muhammad, 2005)

(1) Menjauhkan diri dari unsur riba, caranya

a. Menghindari penggunaan sistem yang menetapkan di muka secara pasti keberhasilan suatu usaha (QS. Luqman, ayat: 34)

b. Menghindari penggunaan sistem bagi presentasi untuk pembebanan biaya terhadap hutang atau pemberian imbalan terhadap simpanan yang mengandung unsur melipatgandakan secara otomatis hutang/simpanan tersebut hanya karena berjalannya waktu (Q.S. Ali'Imron, 130)

c. Menghindari penggunaan sistem perdagangan/penyewaan barang ribawi dengan imbalan barang ribawi lainnya dengan memperoleh kelebihan baik kuantitas maupun kualitas (HR. Muslim Bab Riba No. 1551 s/d 1567)

d. Menghindari penggunaan sistem yang menetapkan di muka tambahan atas hutang yang bukan atas prakarsa yang mempunyai hutang secara sukarela (HR. Muslim, Bab Riba No. 1569 s/d 1572)

(2) Menerapkan sistem bagi hasil dan perdagangan, dengan mengacu pada alquran surah Al Baqarah ayat 275 dan An Nisaa ayat 29, maka setiap transaksi kelembagaan syariah harus dilandasi atas dasar sistem bagi hasil dan perdagangan atau transaksinya didasari oleh adanya pertukaran antara uang dengan barang. Akibatnya pada kegiatan muamalah berlaku prinsip ada barang/jasa uang dengan barang, sehingga akan mendorong produksi barang/jasa, mendorong kelancaran arus barang/jasa, dapat dihindari adanya 
penyalahgunaan kredit, spekulasi dan inflasi

\section{Persepsi}

Menurut Yuniarti (2015) persepsi adalah sebagai proses mengorga-nisasikan dan memaknakan kesan-kesan indra untuk memberikan arti terhadap lingkungannya. Seseorang memersepsikan sesuatu dapat berbeda dengan kenyataan yang objektif. Sedangkan menurut Sunyoto (2014) Persepsi adalah sebagai proses di mana seorang memilih, mengorganisasikan dan mengartikan masukan informasi untuk menciptakan suatu gambaran yang berarti di dunia ini. Persepsi dapat melibatkan penafsiran seorang atas suatu kejadian berdasarkan pengalaman masa lalunya. Sedangkan menurut Rakhmat (2010) bahwa persepsi adalah pengalaman tentang objek, peristiwa, atau hubungan-hubungan yang diperoleh dengan menyimpulkan informasi dan menafsirkan pesan.

\section{Faktor-faktor yang mempenga-ruhi Persepsi}

Menurut Yuniarti (2015) faktor-faktor yang mempengaruhi persepsi adalah penglihatan dan sasaran yang diterima dan situasi persepsi menjadi penglihatan. Tanggapan yang timbul atas rangsangan dipengaruhi sifat-sifat individu yang melihatnya. Sifat yang dapat mempengaruhi persepsi, yaitu sebagai berikut.

1. Sikap, yaitu mempengaruhi positif atau negatifnya tanggapan yang akan diberikan seseorang.

2. Motivasi, yaitu hal yang mendorong seseorang mendasari sikap tindakan yang dilakukannya

3. Minat, yaitu faktor lain yang membedakan penilaian seseorang terhadap suatu hal atau objek tertentu, yang mendasari kesukaan ataupun ketidaksukaan terhadap objek tersebut

4. Pengalaman masa lalu, yaitu dapat mempengaruhi persepsi seseorang karena akan menarik kesimpulan yang sama dengan yang pernah dilihat dan didengar.

5. Harapan, yaitu mempengaruhi pesepsi sesorang dalam membuat keputusan, akan cendrung menolak gagasan, ajakan, atau tawaran yang tidak sesuai dengan yang kita harapkan.

6. Sasaran, yaitu mempengaruhi penglihatan yang akhirnya akan mempengaruhi persepsi.

7. Situasi atau keadaan sekitar kita atau sekitar sasaran yang turut mempengaruhi persepsi. Sasaran atau benda yang sama yang kita lihat dalam situasi yang berbeda akan menghasilkan persepsi yang berbeda pula.

\section{Persepsi Tentang Bunga Bank}

Persepsi masyarakat tentang bunga bank, yang dimaksud dalam penelitian ini adalah persepsi masyarakat tentang hukum bunga bank. Menurut Imaniati (2010) hukum bunga adalah haram, baik dilakukan oleh bank, asuransi, pasar modal, pegadaian, koperasi dan lembaga keuangan lainnya maupun dilakukan oleh individu. Hukum bunga bank sampai saat ini masih menimbulkan kontroversi pendapat tentang keabsahannya. Sebagian fuqaha dan ekonom muslim berpendapat bahwa bunga bank itu bertentangan dengan ajaran agama Islam. Berangkat dari asumsi ini, akhirnya berkembang sistem alternatif perbankan yang menggunakan sistem bebas bunga (interest free banking) agar terhindar dari unsur riba dengan menggunakan sistem bagi hasil (profit and loss sharing).

\section{Persepsi Tentang Sistem Bagi Hasil}

Persepsi tentang sistem bagi hasil adalah persepsi masyarakat bahwa sistem bagi hasil ini lebih sesuai dengan prinsip- prinsip syari'ah, lebih menguntungkan dan telah memenuhi rasa keadilan bagi semua pihak. Menurut Imaniati (2010) sistem bagi hasil adalah suatu sistem yang meliputi tata cara pembagian hasil usaha antara penyedia dana dengan pengelola dana. Pembagian hasil usaha ini dapat terjadi antara bank dengan penyimpan dana maupun antara bank dengan nasabah penerima dana. Bentuk produk berdasarkan prinsip ini adalah mudharobah dan musyarakah. Bank syari'ah adalah perbankan yang memberikan pelayanan kepada nasabah dengan bebas bunga (interestfree banking) tetapi menerapkan sistem bagi hasil (profit and loss sharing).

\section{Persepsi Tentang Pengetahuan Produk}

Persepsi tentang produk bank syari'ah adalah tingkat pengetahuan dan pemahaman masyarakat tentang produk dan 
Imran \& Bambang Hendrawan,Pengaruh Persepsi Masyarakat Batam tentang Bank...

jasa bank syari'ah. Sebagaimana telah dikemukakan oleh beberapa pakar ekonom muslim bahwa salah satu kendala bagi pengembangan bank syari'ah adalah rendahnya pemahaman masyarakat terhadap produk dan operasional bank syari'ah. Untuk itu, perlu adanya penelitian seberapa besar pemahaman masyarakat tentang produk dan jasa bank syari'ah. Persepsi tentang pemahaman terhadap produk dan jasa bank syari'ah akan mempengaruhi perilaku masyarakat dalam berinvestasi dan mengambil dana dari bank syari'ah.

\section{Minat Beli/Minat menggunakan}

Minat Beli dalam dunia bisnis sekarang kita akan sering mengenal dan mendengar berbagai macam taktik atau kiat dari para penjual. Baik penjual partai besar maupun penjual partai kecil dalam menarik dan menggoda para pembeli atau calon pembelinya untuk membeli atau hanya melihat-lihat saja. Pembeli dalam membeli suatu barang dan jasa yang ditawarkan pada pedagang di pasar sering kali berdasarkan pada naluri atau minat. Minat yang timbul dalam diri pembeli seringkali berlawanan dengan kondisi keuangan yang dimiliki. Minat beli konsumen merupakan keinginan tersembunyi dalam benak konsumen. Minat beli konsumen selalu terselubung dalam tiap diri individu yang mana tak seorang pun bisa tahu apa yang diinginkan dan diharapkan oleh konsumen. Minat beli konsumen selalu terselubung dalam tiap diri individu yang mana tak seorang pun bisa tahu apa yang diinginkan dan diharapkan oleh konsumen. Berikut ini akan diberikan beberapa definisi tentang minat beli konsumen dari para ahli pemasaran. Menurut Oentoro (2012) Minat Beli Konsumen adalah inisiatif responden dalam pengambilan keputusan untuk membeli sebuah produk. Sedangkan menurut Schiffman dan Kanuk (2007) Minat beli adalah suatu model sikap seseorang terhadap obyek barang yang sangat cocok dalam mengukur sikap terhadap golongan produk, jasa atau merk tertentu.

\section{Kerangka Pemikiran}

Persepsi Bank Syariah $\left(\mathrm{X}_{\text {) }}\right.$

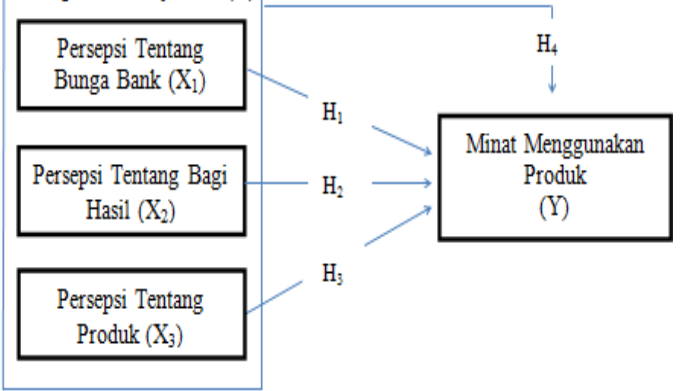

\section{Hipotesis}

$\mathrm{H}_{1}$ : Ada pengaruh positif dan signifikan antara variabel persepsi tentang bunga bank $\left(\mathrm{X}_{1}\right)$ terhadap variabel minat menggunakan produk bank syariah (Y)

$\mathrm{H}_{2}$ : Ada pengaruh positif dan signifikan antara variabel persepsi tentang bagi hasil $\left(\mathrm{X}_{2}\right)$ terhadap variabel minat menggunakan produk bank syariah (Y)

$\mathrm{H}_{3}$ : Ada pengaruh positif dan signifikan antara variabel persepsi tentang pengetahuan produk $\left(\mathrm{X}_{2}\right)$ terhadap variabel minat menggunakan produk bank syariah $(\mathrm{Y})$

$\mathrm{H}_{4}$ : Ada pengaruh positif dan signifikan antara variabel persepsi tentang bunga bank $\left(\mathrm{X}_{1}\right)$, bagi hasil $\left(\mathrm{X}_{2}\right)$ dan pengetahuan produk $\left(\mathrm{X}_{3}\right)$ terhadap variabel minat menggunakan produk bank syariah $(\mathrm{Y})$

\section{METODE PENELITIAN \\ Rancangan Penelitian}

Rancangan penelitian yang penulis gunakan adalah penelitian eksplanatori yang merupakan suatu penelitian yang mencari dan menjelaskan pengaruh keterkaitan antara variabel satu dengan variabel lainnya melalui beberapa pertanyaan atau pernyataan penelitian.

Penelitian yang akan dilakukan merupakan penelitian kuantitatif yang dilakukan dalam satu waktu tertentu dengan mengambil seluruh anggota populasi menjadi sampel (sensus). Pada penelitian ini digunakan teknik survei dengan menyebarkan kuesioner, selanjutnya data atau informasi yang diperoleh akan diolah dengan menggunakan sortware statistik yaitu SPSS.

\section{Populasi dan Sampel}

\section{Populasi}

Menurut Sugiono (2008), populasi adalah wilayah generalisasi yang terdiri atas: objek/subjek yang mempunyai kualitas dan karakteristik tertentu yang diterapkan oleh peneliti untuk dipelajari dan kemudian ditarik kesimpulannya. Dalam penelitian ini yang menjadi populasi adalah Masyarakat Citra Batam

\section{Sampel}

Menurut Sugiono (2008) Sampel adalah subset dari populasi, terdiri dari 
beberapa anggota populasi Pengambilan sampel dilakukan dengan pertimbangan bahwa populasi yang ada sangat besar jumlahnya, sehingga tidak memungkinkan untuk meneliti seluruh populasi yang ada, sehingga dibentuk sebuah perwakilan populasi. Metode pengambilan sampel yang digunakan adalah Accidental Sampling Method yaitu pengambilan sampel secara kebetulan siapa saja yang ditemui dan memenuhi kriteria untuk menjadi sampel Perwakilan populasi yang dijadikan sampel adalah Batam Center khususnya Citra Batam yang kebetulan ditemui pada saat melakukan pembagian kuesioner. Masyarakat yang menjadi sampel adalah masyarakat Batam Center yang belum menjadi nasabah Bank Syariah, yang berjumlah 100 orang sampel.

\section{Validitas dan Reliabilitas}

\section{Validitas}

Dari hasil pengujian validitas diperoleh nilai $r$ hitung seluruh pernyataan pada variabel persepsi tentang bunga bank $\left(\mathrm{X}_{1}\right)$, Persepsi Tentang Sistem Bagi Hasil $\left(\mathrm{X}_{2}\right)$, Persepsi Tentang Produk $\left(\mathrm{X}_{3}\right)$ dan minat menggunakan produk bank syariah $(\mathrm{Y})$, lebih besar dari $\mathrm{r}$ tabel yaitu 0.195 , sehingga dapat ditarik kesimpulan bahwa seluruh butir pernyataan dinyatakan lolos uji validitas dan dinyatakan layak digunakan sebagai alat ukur dalam penelitian ini.

\section{Reliabilitas}

Keempat variabel yaitu persepsi tentang bunga bank, persepsi tentang sistem bagi hasil, persepsi tentang produk dan minat mengunakan produk bank syariah mendapat nilai Cronbach's Alpha $>0,60$, sehingga keempat variabel penelitian tersebut dinyatakan reliabel.

\section{Teknik Analisis Data}

Teknik analisis data yang digunakan pada penelitian ini menggunakan model analisis linier berganda. Agar model tersebut dapat memberikan hasil yang tidak bias, dilakukan pengujian asumsi klasik terlebih dahulu di mana hasilnya adalah sebagai berikut:

\section{Uji Asumsi Klasik}

\section{Uji Normalitas}

Menggunakan grafik normal probability plot diperoleh hasil bahwa seluruh data mengikuti arah garis diagonal, sehingga menunjukkan bahwa model regresi memenuhi asumsi normalitas

\section{Uji Multikorelinieritas}

Dari hasil pengolahan data menggunakan bantuan SPSS versi 17 for windows diperoleh hasil pada tabel sebagai berikut

Tabel 1 Uji Multikorelinieritas

\begin{tabular}{|l|l|c|c|}
\hline No & \multicolumn{1}{|c|}{ Variabel } & $\begin{array}{c}\text { Toleranc } \\
\text { e }\end{array}$ & VIF \\
\hline 1 & $\begin{array}{l}\text { Persepsi Tentang } \\
\text { Bunga Bank }\end{array}$ & 0.616 & 1,623 \\
\hline 2 & $\begin{array}{l}\text { Persepsi Tentang } \\
\text { Sistem Bagi Hasil }\end{array}$ & 0,536 & 1,867 \\
\hline 3 & $\begin{array}{l}\text { Persepsi } \\
\text { Tentang } \\
\text { Pengetahuan } \\
\text { Produk }\end{array}$ & 0,703 & 1,422 \\
\hline
\end{tabular}

Sumber: Data diolah, 2017

Berdasarkan tabel di atas, diketahui bahwa nilai tolerance ketiga variabel independen lebih dari 0.10 dan nilai VIF kurang dari 10, maka dapat disimpulkan bahwa tidak terjadi multikolinieritas antar variabel bebas.

\section{Uji Heterokedastisitas}

Berdasarkan pola yang terlihat pada grafik scatter plot antara regression standardized predicted value dengan regression standardized residual, diperoleh bahwa titik-titik data menyebar secara acak, baik di bagian atas atau bagian bawah angka 0 pada sumbu Y dan tidak ada pola tertentu yang membentuk. Sehingga dapat disimpulkan bahwa pada data dalam penelitian ini tidak terjadi heterokedastisitas yang berarti fungsi regresi dalam penelitian ini tidak memiliki gangguan yang muncul karena ketidaksamaan varian.

\section{HASIL DAN PEMBAHASAN}

\section{Karakteristik \\ Jenis Kelamin}

Jumlah responden laki-laki lebih banyak dibandingkan responden perempuan. Responden laki-laki sebanyak 61 orang dengan presentase $61 \%$ dan jumlah responden 
Imran \& Bambang Hendrawan,Pengaruh Persepsi Masyarakat Batam tentang Bank...

perempuan sebanyak 39 orang dengan presenase $39 \%$.

\section{Agama}

Jumlah responden masih didominasi responden yang beragama Islam sebanyak 83 orang $(83 \%)$, diikuti responden yang beragama Kristen sebanyak 12 orang (12\%), Katolik sebanyak 3 Orang (3\%) dan Budha sebanyak 2 Orang ( $2 \%$ ).

\section{Usia}

Jumlah responden yang terbanyak dari sisi usia adalah responden yang berusia 20-30 tahun dan yang berusia 41-50 tahun dengan jumlah responden yang sama yaitu masingmasing berjumlah 29 orang atau masingmasing 29\% dari total responden. Kemudian, diikuti dengan responden berusia 31-40 tahun sejumlah 27 orang $(27 \%)$, responeden berusia 51-60 tahun sejumlah 9 orang (9\%) dan responden berusia 17-20 tahun sejumlah 3 orang $(3 \%)$.

\section{Pendidikan}

Jumlah responden dari sisi tingkat pendidikan yang banyak berasal dari responden dengan tingkat pendidikan SLTA sejumlah 52 orang atau $52 \%$ dari total responden. Diikuti berturut-turut responden dengan tingkat pendidikan sarjana/sarjana terapan sebanyak 22 orang (22\%), responden berpendidikan SLTP sebanyak 10 orang $(10 \%)$, responden berpendidikan Magister dan juga responden yang berpendidikan SD, sama-sama berjumlah 3 orang atau masing-masing $3 \%$ dari total responden.

\section{Pekerjaan}

Dari sisi jenis pekerjaan responden, jumlah responden paling banyak adalah yang bekerja sebagai karyawan swasta sebanyak 46 orang atau $46 \%$ dari total responden. Diikuti kemudian oleh responden yang berwiraswasta sebanyak 31 orang (31\%), responden bekerja sebagai PNS/BUMN sebanyak 10 orang $(10 \%)$, respoden yang bekerja sebagai tenaga pengajar dan yang tidak ada pekerjaan sama-sama jumlahnya sebanyak 2 orang (2\%), responden yang masih pelajar SLTA 1 orang $(1 \%)$ dan sisanya sebanyak 8 orang $(8 \%)$ bekerja di bidang lain di luar bidang yang telah yang telah disebutkan

\section{Penghasilan Perbulan}

Jumlah responden terbanyak dari sisi besaran penghasilan sebulan adalah responden yang berpenghasilan Rp 2-3 juta yaitu sebanyak 35 orang atau $35 \%$ dari total responden, diikuti secara berturut-turut oleh responden yang berpenghasilan $\mathrm{Rp}$ 4-5 sebanyak 25 orang (25\%), responden yang berpenghasilan > 5 juta sebanyak 21 orang (21\%), dan terakhir responden yang berpenghasilan Rp 3-4 juta sebanyak 19 orang $(19 \%)$

\section{Hasil Analisis Regresi Linier Berganda}

Dari hasil yang telah dilakukan, maka didapatkan hasil nilai regresi berganda sebagai berikut:

Tabel 2 Uji Regresi Berganda

\begin{tabular}{|ll|r|r|}
\hline \multirow{2}{*}{ Model } & \multicolumn{2}{|c|}{ Unstandardized Coefficients } \\
\cline { 3 - 4 } & \multicolumn{2}{|r|}{ B } & Std. Error \\
\hline 1 & (Constant) & 7.698 & 1.815 \\
& Bunga Bank & .179 & .086 \\
& Bagi_Hasil & .298 & .120 \\
& Pengetahuan Produk & .160 & .097 \\
\hline
\end{tabular}

Sumber: Data diolah, 2017

$$
\begin{aligned}
& Y=7,698+0,179 X_{1}+0,298 X_{2}+0,160 \\
& X_{3}
\end{aligned}
$$

Interpretasi persamaan linier sebagai berikut:

1. Konstanta (B) memiliki nilai sebesar 7,698 dengan ini menunjukkan jika bunga bank $\left(X_{1}\right)$, bagi hasil $\left(X_{2}\right)$, dan produk $\left(X_{3}\right)$ nilai adalah nol, maka minat menggunakan produk (Y) memiliki nilai 7.698.

2 Pada variabel bunga bank $\left(\mathrm{X}_{1}\right)$ memiliki nilai koefiisien regeresi sebesar 0.179 , ini berarti jika variabel independen lain nilainya tetap atau tidak berubah, maka setiap kenaikan 1 poin atau $1 \%$ variabel bunga bank $\left(\mathrm{X}_{1}\right)$ bernilai positif sehingga terdapat hubungan positif antara bunga bank $\left(\mathrm{X}_{1}\right)$ dengan minat menggunakan produk (Y). artinya semakin meningkat nilai bagi hasil $\left(\mathrm{X}_{1}\right)$ maka akan meningkatkan minat menggunakan produk (Y).

3. Pada variabel bagi hasil $\left(\mathrm{X}_{2}\right)$ memiliki nilai koefisien regresi sebesar 0.298, ini 
berarti jika variabel independen lain nilainya tetap atau tidak berubah, maka setiap kenaikan 1 poin atau $1 \%$ variabel bagi hasil $\left(\mathrm{X}_{2}\right)$ bernilai positif sehingga terdapat hubungan positif antara bagi hasil (X2) dengan minat menggunakan produk (Y). Artinya semakin meningkat nilai bagi hasil (X2) maka akan meningkatkan minat menggunakan produk (Y).

4. Pada variabel produk $\left(X_{3}\right)$ memiliki nilai koefisien regresi sebesar 0.179 , ini berarti jika variabel independen lain nilainya tetap atau tidak berubah, maka setiap kenaikan 1 poin atau $1 \%$ variabel produk $\left(\mathrm{X}_{3}\right)$ bernilai positif sehingga terdapat hubungan positif antara produk $\left(X_{3}\right)$ dengan minat menggunakan produk (Y). Artinya semakin meningkat nilai produk $\left(\mathrm{X}_{3}\right)$ maka akan meningkatkan minat menggunakan produk $(\mathrm{Y})$.

\section{Uji t (Parsial)}

Uji t digunakan untuk mengetahui apakah secara parsial persepsi tentang bunga bank, persepsi tentang bagi hasil dan persepsi tentang pengetahuan produk berpengaruh secara signifikan atau tidak berpengaruh terhadap minat menggunakan produk bank syariah. berikut ini hasil perhitungannya:

Tabel 3 Uji t

\begin{tabular}{|ll|l|r|}
\hline Model & & T & Sig. \\
\hline 1 & (Constant) & 4.24 & .000 \\
& & 1 & \\
& Bunga_Bank & 2.08 & .040 \\
& & 1 & \\
& Bagi_Hasil & 2.49 & .014 \\
& & 3 & \\
& Pengetahuan_Prod & 1.65 & .102 \\
& u k & 2 & \\
\hline
\end{tabular}

Sumber: Data diolah, 2017

Berdasarkan tabel diatas dapat disimpulkan bahwa:

1. Uji Hipotesis 1

Hipotesis $\mathrm{Ha}$ menyatakan terdapat pengaruh yang signifikan antara variabel persepsi tentang bunga bank terhadap minat menggunakan produk bank syariah. Hasil uji statistik diperoleh nilai $t$ untuk variabel persepsi tentang bunga bank $\left(\mathrm{X}_{1}\right)$ adalah $\mathrm{t}_{\text {hitung }}>\mathrm{t}_{\text {tabel }}(2,081>$ $1,985)$ dan signifikasi $<0.05(0.014<$
0.05) maka $\mathrm{H}_{0}$ ditolak dan $\mathrm{H}_{1}$ diterima, jadi dapat disimpulkan bahwa bunga bank $\left(\mathrm{X}_{1}\right)$ secara parsial berpengaruh signifikan terhadap minat menggunakan produk bank syariah (Y).

2. Hipotesis 2

Hipotesis Ha menyatakan terdapat pengaruh yang signifikan antara variabel persepsi tentang bagi hasil terhadap minat menggunakan produk bank syariah. Hasil uji statistik diperoleh nilai $t$ untuk variabel persepsi tentang bunga bank $\left(\mathrm{X}_{2}\right)$ adalah $t_{\text {hitung }}>t_{\text {tabel }}(2,493>1,985)$ dan signifikasi $<$

$0.05(0.014<0.05)$ maka $\mathrm{H}_{0}$ ditolak dan $\mathrm{H}_{1}$ diterima, jadi dapat disimpulkan bahwa bagi hasil $\left(\mathrm{X}_{2}\right)$ secara parsial berpengaruh signifikan terhadap minat menggunakan produk bank syariah (Y).

3. Hipotesis 3

Hipotesis Ha menyatakan terdapat pengaruh yang signifikan antara variabel persepsi tentang pengetahuan produk terhadap minat menggunakan produk bank syariah. Hasil uji statistik diperoleh nilai $t$ untuk variabel persepsi tentang bunga bank $\left(\mathrm{X}_{3}\right)$ adalah $\mathrm{t}_{\text {hitung }}<\mathrm{t}_{\text {tabel }}(1,652<1,985)$ dan signifikasi $>$

0.05 (0.102 > 0.05) maka $\mathrm{H}_{0}$ diterima dan $\mathrm{H}_{1}$ ditolak, jadi dapat disimpulkan bahwa produk $\left(\mathrm{X}_{3}\right)$ secara parsial tidak berpengaruh signifikan terhadap minat menggunakan produk bank syariah (Y).

\section{Uji F (Simultan)}

Uji $\mathrm{F}$ digunakan untuk menguji ada tidaknya pengaruh secara signifikan beberapa variabel independen (persepsi tentang bunga bank, persepsi tentang bagi hasil dan persepsi tentang pengetahuan produk) terhadap variabel dependen (minat menggunakan produk bank syariah). Hasilnya ditampilkan pada tabel sebagai berikut:

Tabel 4 Uji F

\begin{tabular}{|l|l|c|c|}
\hline \multicolumn{2}{|l|}{ Model } & F & $\begin{array}{c}\text { Sig } \\
.\end{array}$ \\
\hline 1 & Regression & $\begin{array}{l}15.01 \\
1\end{array}$ & $\begin{array}{l}.000 \\
\mathrm{a}\end{array}$ \\
\hline
\end{tabular}

Sumber: Data diolah, 2017 
Imran \& Bambang Hendrawan,Pengaruh Persepsi Masyarakat Batam tentang Bank...

Hipotesis 4

Hipotesis Ha menyatakan variabel-variabel bebas persepsi tentang bunga bank (X1), persepsi tentang bagi hasil (X2) dan persepsi tentang pengetahuan produk (X3) mempunyai pengaruh yang signifikan secara bersama-sama terhadap variabel terikatnya yaitu minat menggunakana produk bank syariah (Y). Hasil uji statistik $\mathrm{F}$ menghasilkan nilai $\mathrm{F}_{\text {hitung }}>\mathrm{F}_{\text {tabel }}(15,011$ $>2,70)$ dan signifikasi $<0,05(0.000<0,05)$ maka $\mathrm{H}_{0}$ ditolak dan $\mathrm{H}_{\mathrm{a}}$ diterima. Berdasarkan kriteria tersebut maka hipotesis 4 diterima, artinya bahwa bunga bank bank $\left(\mathrm{X}_{1}\right)$ bagi hasil $\left(\mathrm{X}_{2}\right)$ dan Produk $\left(\mathrm{X}_{3}\right)$ berpengaruh secara bersama-sama (simultan) terhadap minat menggunakan produk bank syariah (Y).

\section{Uji Deteminasi}

Nilai koefisien korelasi (R) menunjukkan keeratan hubungan antara 3 variabel. Nilai koefisien korelasi berkisar 0 sampai 1. Maka hubungan semakin erat, jika mendekati 0 maka hubungan semakin lemah

Tabel 5 Uji Determinasi

\begin{tabular}{|l|r|r|r|}
\hline Model & \multicolumn{1}{|c|}{$\mathrm{R}$} & R Square & \multicolumn{1}{|c|}{$\begin{array}{c}\text { Adjusted R } \\
\text { Square }\end{array}$} \\
\hline 1 & .565 & .319 & .29 \\
\hline
\end{tabular}

Sumber: Data diolah, 2017

Berdasarkan data pada tabel di atas, diketahui bahwa nilai koefisien $(\mathrm{R})$ adalah 0,565 sehingga terjadi hubungan yang erat antara persepsi tentang bunga bank, persepsi tentang bagi hasil dan persepsi tentang pengetahuan produk terhadap minat menggunakan produk bank syariah. Koefisien determinasi (R Square) mempunyai nilai 0,319 artinya presentase pengaruh variabel persepsi tentang bunga bank, persepsi tentang bagi hasil dan persepsi tentang pengetahuan produk sebesar 31,9\%, sedangkan sisanya dipengaruhi oleh variabel lain yang tidak diteliti.

\section{SIMPULAN DAN SARAN}

\section{Kesimpulan}

Berdasarkan pada hasil penelitian, maka kesimpulan dari penelitian ini adalah sebagai berikut:

1. Bunga bank memiliki pengaruh positif dan signifikan terhadap minat menggunakan produk bank syariah, artinya bahwa semakin tinggi persepsi tentang bunga bank bahwa hukum bunga bank adalah haram, maka akan meningkatkan kepatuhan dan keta'atan nasabah terhadap prinsip-prinsip syariah sehingga dapat mempengaruhi minat menggunakan produk bank Syariah

2. Bagi hasil memiliki pengaruh positif dan signifikan terhadap minat menggunakan produk bank syariah, artinya bahwa semakin tinggi persepsi tentang sistem bagi hasil itu sudah sesuai dengan syariah Islam akan meningkatkan kepercayaan dan keyakinan masyarakat sehingga dapat mempengaruhi minat menggunakan produk bank syariah.

3. Pengetahuan mengenai produk tidak memiliki pengaruh signifikan terhadap minat menggunakan produk bank syariah, artinya bahwa masyarakat berminat menggunakan bank syariah itu bukan karena mengetahui atau tidaknya mengenai produk bank syariah, tetapi karena hal yang lain seperti hukum bunga bank, sistem bagi hasil dan lain sebagainya

4. Secara simultan bunga bank, bagi hasil dan pengetahuan mengenai produk bank bank syariah memiliki pengaruh yang signifikan terhadap minat menggunakan produk bank syariah, artinya bahwa minat menggunakan produk bank syariah muncul karena hukum bunga dalam Islam dilarang dan juga sistem yang diterapkan harus sesuai dengan syariah Islam seperti sistem bagi hasil.

\section{Saran bagi peneliti selanjutnya}

Adapun saran untuk peneliti selanjutnya sebagai berikut:

1. Dalam penelitian ini ketiga variabel independen bunga bank $\left(\mathrm{X}_{1}\right)$ bagi hasil $\left(\mathrm{X}_{2}\right)$ dan pengetahuan Produk $\left(\mathrm{X}_{3}\right)$ hanya mampu menjelaskan sekitar $15 \%$ dari variasi variabel dependen (Y), sehingga diharapkan pada penelitian selanjutnya dapat mencari atau mengembangkan faktor-faktor lain

2 Untuk penelitian yang akan datang disarankan untuk mencari ruang lingkup yang cakupannya lebih luas, seperti populasi yang berbeda dan menggunakan sampel lebih banyak 
daripada sampel dalam penelitian ini

\section{DAFTAR PUSTAKA}

Abdullah, Saeed (1996) Islamic Banking and Interest, A Study of Prohibition of Riba and its Contemporary Interpretation (Leiden: E.J. Brill, 1996)

Abhimantra, Ananggadipa, dkk. (2013). Analisis Faktor-faktor yang Mempengaruhi Nasabah (Mahasiswa) dalam memilih Menabung pada Bank Syariah, Jurnal Procesding PESAT, ISSN 18582559, Jurusan Akuntasnsi, Universitas Gunadarma

Ahktar, Naeem, Dkk. (2016). Faktors Influencing the Perception on Customers in Islamic Bank: A Case Study in Pakistan, Jurnal International Management and Business Research, ISSN 23069007, University of Okara (Punjab) Pakistan

Cahyani. A. F. (2013). Pengaruh Persepsi Bunga Bank dan Kualitas Layanan Terhadap Minat Menabung pada Bank BNI Syariah di Kota Semarang, Jurnal social and politik, Jurusan Administrasi Bisnis, Universitas di Ponegoro

Ghozali, Imam. (2006). Aplikasi Analisis Multivariate dengan Program SPSS. Semarang: Badan Penerbit Universitas Diponegoro.

Imaniati, Neni sri (2010). Pengantar Hukum Perbankan Indonesia, Penerbit PT. Refika Aditama, Jl. Mengger Girang No. 98, Bandung

Kamarni, Neng (2012) Faktor-faktor yang mempengaruhi minat masyarakat dalam berhubugan dengan bank syarian di Kota Padang, Jurnal. Manajemen dan kewirausahaan, Volume 3, Nomor 1, ISSN: 20865031, Universitas Andalas, Padang

Lovenia, Christiana Okky. A (2012) Analisis Pengaruh Kualitas Pelayanan Terhadap Kepuasan Nasabah, Skripsi Program sarjana, Universitas Diponegoro.

Muhammad (2005). Manajemen Pembiayaan Bank Syariah.
Yogyakarta. UPP AMP YKPN

Oentoro, D. 2012, Manajemen Pemasaran Modern, Edisi Kesembilan, Jilid 1 dan jilid 2, Jakarta, Prehalindo, Penerbit LaksBang PRESSindo, Yogyakarta.

QS. Luqman, ayat: 34

Q.S. Ali'Imron, 130

Rahmawanty, A (2014). Pengaruh Persepsi Tentan Bank Syariah Terhadap Minat Mengunakan Produk di Bank BNI Syariah Semarang, Vol. 8. Stain Kudus Jawa Tengah

Schiffman,Leon G dan Kanuk, Lesley L, (2007), Panduan Riset Perilaku Konsumen, Gramedia Pustaka Utama, Jakarta.

Sholihin, Ahmad Ifham. (2010). Buku Pintar Ekonomi Syariah: Penerbit Gramedia Pustaka Utama, Jakarta

Sugiyono, (2008). Metode Penelitian Kuantitatif, Kualitatif dan $R \& D$. $C v$. Alfabeta: Bandung

Sunyoto, Danang (2014). Konsep Dasar Riset Pemasaran dan Perilaku Konsumen, Jakarta, CAP (Center for Academic Publishing Service)

Yamin, Regina (2009) Persepsi Nilai, Persepsi kualitas, dan Citra Merek Terhadap Kepuasan Konsumen Pada PT. Astra International Daihatsu di Manado, Jurnal Ekonomi dan Bisnis, Universitas Sam Ratulangi Manado.

Yuniarti, Vinna, Sri (2015). Perilaku Konsumen Teori dan Praktik, Penerbit Pustaka Setia, Bandung 